Kumawula, Vol. 4, No.1, April 2021, Hal 183 - 190

DOI: https://doi.org/10.24198/kumawula.v4i1.32427

ISSN 2620-844X (online)

Tersedia online di http://jurnal.unpad.ac.id/kumawula/index

\title{
KONSTRUKSI SOSIAL MASYARAKAT MELALUI KONTEN EDUKATIF MENGENAI KETAHANAN AIR
}

\author{
Desi Yunita $^{1}$, Bintarsih Sekarningrum ${ }^{2}$ \\ ${ }^{1}$ Departemen Sosiologi Universitas Padjadjaran \\ ${ }^{2}$ Departemen Sosiologi Universitas Padjadjaran \\ *Korespondensi : desi.yunita@unpad.ac.id
}

\begin{abstract}
This activity is intended to increase public awareness about why water resilience is important. Efforts to improve community water resilience done by providing educational content containing messages on water resilience through booklets, posters, animations, or short videos about how to increase water resilience practically by the community. So that the message of this water resilience campaign is spread to the wider community, these educational media are disseminated online via social media or shared directly when done face-to-face virtually. The method of dissemination through dissemination through social media or virtual presentations is chosen so that the message can be received appropriately while maintaining health protocols. So, even though it is still hit by a pandemic, the public can still be invited to participate in this activity.
\end{abstract}

Keywords: Educational content, awareness, water resilience

\begin{abstract}
ABSTRAK
Kegiatan ini bertujuan untuk meningkatkan kesadaran masyarakat tentang pentingnya ketahanan air. Upaya peningkatan ketahanan air masyarakat dilakukan dengan memberikan konten edukasi yang berisi pesanpesan tentang ketahanan air melalui booklet, poster, animasi, atau video pendek tentang bagaimana cara meningkatkan ketahanan air secara praktis oleh masyarakat. Agar pesan kampanye ketahanan air ini tersebar ke masyarakat luas, media edukasi ini disebarluaskan secara online melalui media sosial atau dibagikan secara langsung saat kegiatan tatap muka secara virtual dilakukan. Metode penyebaran melalui sosialisasi melalui media sosial atau presentasi virtual dipilih agar pesan dapat diterima dengan tepat dengan tetap menjaga protokol kesehatan. Jadi, meski masih dilanda pandemi, masyarakat tetap bisa diajak untuk mengikuti kegiatan ini.
\end{abstract}

Kata Kunci: Konten edukatif, kesadaran, Ketahanan air

\section{PENDAHULUAN}

Penyebaran virus corona yang begitu cepat membuat World Health Organization (WHO) menetapkan status Covid-19 menjadi pandemi pada bulan Maret tahun 2020 (Lawrenche et al., 2020). Akibatnya, anjuran untuk tinggal di rumah sementara waktu yang terjadi karena merebaknya wabah Covid-19 di seluruh penjuru dunia di awal tahun 2020 telah mendorong perubahan dalam permintaan air khususnya di wilayah perkotaan, meskipun data yang dimiliki terbatas namun secara intuisi, permintaan air perumahan mengalami peningkatan, sedangkan non-perumahan mengalami penurunan. Misalnya seperti yang terjadi di Portsmouth Inggris, di mana permintaan air rumah tangga meningkat 15 persen selama lockdown, sedangkan permintaan non-rumah tangga turun 17 persen, meskipun pada bulan juni permintaan air non rumah 
tangga telah kembali ke tingkat sebelum Covid19. Hal yang tidak jauh berbeda juga terjadi di Amerika Serikat yang mana selama pandemi berlangsung, permintaan air untuk kebutuhan rumah tangga di San Francisco, California meningkat 10 persen, sedangkan permintaan non rumah tangga turun 32 persen (Cooley, et.al. 2020).

Di Indonesia, meskipun penerapan lockdown yang dilakukan sedikit berbeda dengan yang dilakukan di banyak negaranegara lain, namun indikasi adanya peningkatan penggunaan air khususnya untuk rumah tangga juga terlihat. Indonesian Water Institute (IWI) dalam siaran persnya, mengungkapkan bahwa pandemi Covid-19 telah menambah angka krisis air nasional karena pandemi telah merubah perilaku masyarakat dalam menggunakan air di rumah tangga. IWI menyebutkan bahwa konsumsi air untuk mandi berada di kisaran 50-70 liter per orang per hari. Angka tersebut naik 300 persen ke level 150210 liter per orang per hari selama pandemi Covid-19. Selanjutnya IWI juga mengungkapkan bahwa, lonjakan konsumsi air tersebut juga terjadi karena aktivitas mencuci tangan yang kian meningkat selama pandemi, jika sebelum pandemi diketahui hanya sekitar 18 persen masyarakat yang mencuci tangan lebih dari 10 kali per hari. Namun ketika pademi terjadi lonjakan, angka tersebut meningkat menjadi 82 persen. Data tersebut membuktikan bahwa selama masa pandemi Covid-19 penggunaan air juga mengalami peningkatan secara signifikan. Itu artinya potensi kerentanan sosial pada masyarakat akibat berkurangnya air juga semakin besar.

Kekhawatiran akan meningkatnya potensi kerentanan sosial pada masyarakat terhadap air ini bukanlah hal yang tidak beralasan, karena jika dilihat dari kemampuan pemerintah untuk menyediakan air bersih dengan sistem perpipaan belum mencapai 25 persen, sehingga peluang untuk meningkatnya kerentanan sosial pada masyarakat khususnya masyarakat menengah ke bawah menjadi semakin besar. Ditambah lagi, jika merujuk pada data Bappenas yang menyebutkan bahwa hingga tahun 2018 masyarakat yang dapat mengakses air minum layak baru mencapai $87,75 \%$ dengan akses perpipaan baru mencapai 20,14\% (Purwanto, 2020). Data tersebut menunjukkan bahwa belum semua masyarakat dapat mengakses air yang layak apalagi dengan perpipaan teknis yang layak. Data tersebut secara tidak langsung menjadi warning bagi kita semua, bahwa dengan kondisi seperti pada data tersebut, maka sangat memungkinkan bagi masyarakat kita untuk mengalami kerentanan air tersebut.

Kerentanan sosial adalah salah satu dimensi kerentanan terhadap berbagai penyebab stres dan guncangan, seperti pelecehan, pengucilan, dan bahaya alam. Kerentanan sosial mengacu pada ketidakmampuan orang, organisasi, atau masyarakat untuk menahan dampak merugikan dari berbagai penyebab stress yang dihadapi. Dampak ini sebagian disebabkan oleh karakteristik yang melekat dalam interaksi sosial, kelembagaan, dan sistem nilai budaya (Peacock, et.al. 1997; Anderson, Mary B \& Woodrow, Peter J (1998); Alwang, et.al, 2001; Conway, Tim \& Norton, Andi, 2002). Kejadian pandemi Covid-19 yang melanda sejak awal tahun 2020 ini jika mengacu pada uraian tersebut, dapat juga dimaknai sebagai penyebab stres sosial masyarakat, masyarakat yang selama ini bebas beraktivitas namun saat ini mengalami batasan yang diakibatkan oleh wabah Covid-19 tersebut. Wabah tersebut juga menjadi penyebab stress sosial karena setiap individu masyarakat berusaha sedemikian rupa untuk terhindar dari wabah ini, oleh karena itu berbagai upaya dilakukan oleh masyarakat agar terhindar dari wabah Covid-19 ini termasuk dengan menggunakan air secara berlebihan. Stres sosial juga dimungkinkan terjadi karena meningkatnya pengeluaran rumah tangga masyarakat sementara di sisi lain pemasukan juga mengalami kendala akibat timbulnya pandemi Covid-19 tersebut. Dalam hal ini fakta yang paling banyak ditemukan selama pandemi Covid-19 adalah banyaknya masyarakat yang kehilangan pekerjaan, sehingga kesulitan untuk memenuhi kebutuhan sehari-hari khususnya pangan (Gunawan \& Kusuma, 2020) 
Melihat potensi risiko kerentanan terhadap air yang muncul khususnya di masamasa pandemi Covid-19 sekarang ini, maka dirasa perlu untuk mengedukasi masyarakat tentang ketahanan air. Selain agar efektif dalam pemanfaatan air, juga agar menekan biaya rutin yang harus dikeluarkan setiap bulannya untuk memenuhi kebutuhan air tersebut. salah satu strategi memberikan edukasi untuk meningkatkan ketahanan air di masa pandemi Covid-19 ini adalah dengan menyediakan konten-konten edukatif bermuatan pengetahuan tentang meningkatkan ketahanan air baik itu melalui penyebaran secara online ataupun penyebaran informasi melalui pertemuanpertemuan yang digagas secara virtual.

\section{Konstruksi sosial dan Ketahanan Air}

Konstruksi sosial adalah makna, gagasan, atau konotasi yang ditempatkan pada suatu objek atau peristiwa oleh suatu masyarakat, dan diadopsi oleh masyarakat lainnya sehubungan dengan cara mereka memandang atau menangani objek atau peristiwa, dengan kata lain dapat dikatakan teori konstruksi sosial ini berpusat pada gagasan bahwa makna atas sesuatu dikembangkan dalam koordinasi dengan orang lain daripada secara terpisah dalam setiap individu (LeedsHurtwitz, 2009). Konstruksi sosial memiliki beberapa kekuatan, pertama, peran sentral bahasa memberikan mekanisme konkret, di mana budaya mempengaruhi pikiran dan tingkah laku individu; kedua, konstruksi sosial dapat mewakili kompleksitas dalam satu budaya tunggal, hal ini tidak mengasumsikan keseragaman; ketiga, hal ini bersifat konsisten dengan masyarakat dan waktu (Ngangi, 2011). Selain itu, konstruksi sosial juga dapat dilihat lemah dan kuatnya. Konstruksi sosial dinilai lemah jika bergantung pada fakta kasar atau fakta fundamental yang sulit dipahami atau fakta kelembagaan yang dibentuk dari konvensi sosial. Sedangkan konstruksi sosial yang kuat bergantung pada perspektif dan pengetahuan manusia yang tidak hanya ada, tetapi dibangun oleh masyarakat. Namun meskipun begitu, konstruksi sosial dapat berbeda berdasarkan masyarakat dan peristiwa di sekitar periode waktu di mana mereka ada. Oleh karenanya, suatu konstruksi sosial akan bermakna ketika konstruksi sosial tersebut dilakukan pada suatu keadaan, kondisi atau peristiwa sosial yang yang menuntut sesuatu yang ideal di dalam masyarakat.

Adapun konsep ketahanan jika ditelusuri, konsep ini memiliki sejarah yang cukup panjang, yang mana akar sejarah mengenai gagasan ketahanan adalah hasil dari rantai proses transfer yang terjadi antara berbagai bidang pengetahuan dan sains (Reisemann, et.al. 2018). Namun secara sederhana dapat dijelaskan bahwa konsep ketahan pertama kali muncul dalam bidang kajian ekologi pada tahun 1970-an, di mana kemunculan konsep ini untuk menggambarkan kapasitas sistem untuk mempertahankan atau memulihkan keberfungsiannya jika terjadi gangguan ataupun kekacauan. Selanjutnya, ide ketahanan tersebut mengalami perkembangan yang signifikan pada disiplin-disiplin ilmu lainnya baik ilmu alam maupun ilmu-ilmu humaniora (Fletcher, 2019). Definisi ketahanan sendiri jika merujuk pada denifisi UNISDR (2009) adalah "kemampuan suatu sistem, komunitas, atau masyarakat yang terpapar bahaya untuk melawan, menyerap, mengakomodasi, dan memulihkan diri dari upaya bahaya secara tepat waktu dan efisien (Johannessen, A \& Christine Wamsler, 2017).

Sehingga berdasarkan uraian tersebut, konstruksi sosial dalam konteks ketahanan air adalah sesuatu hal yang diupayakan bersama oleh suatu masyarakat untuk mendapatkan sesuatu yang ideal dalam hal ini adalah air yang memiliki keberlanjutan dan kepastian. Di sisi lain, ketahanan tersebut adalah sesuatu yang harus diupayakan secara terus menerus karena ketahanan sendiri tidak terlepas dari pengaruhpengaruh internal maupun eksternal suatu masyarakat. Dalam upaya mendapatkan air yang memiliki ketahanan tersebutlah kegiatan ini dilakukan, meskipun untuk mendapatkan ketahanan air tersebut membutuhkan dukungan dari seluruh elemen masyarakat, namun setidaknya dengan memberikan edukasi melalui konten-konten edukatif ini diharapkan dapat memberikan cara pandang baru bagi masyarakat dalam memanfaatkan air. 


\section{METODE}

Ada dua metode yang dipilih pada kegiatan ini sebagai upaya untuk mengkonstruksi pemahaman masyarakat akan pentingnya meningkatkan ketahanan air yaitu; pertama, dengan menyebarkan informasi atau konten-konten edukatif yang telah dibuat langsung kepada masyarakat mitra yang telah dipilih berdasarkan komunikasi yang telah dibangun sebelumnya; kedua, melalui penyebaran konten-konten edukatif yang telah dibuat dalam kanal-kanal media sosial secara virtual seperti Youtube, grup-grup Whatsapp, ataupun melaui pertemuan pertemuan virtual yang telah digagas.

Pada metode pertama, konten-konten edukatif diberikan secara langsung dalam format digital sehingga mudah untuk dilihat secara langsung di gadget yang masyarakat miliki. Selain itu, masyarakat yang telah mendapatkan konten-konten ketahanan air tersebut juga diharapkan untuk dapat menyebarkannya kejaringan-jaringan pertemanan yang dimilikinya sehingga semakin banyak masyarakat yang dapat melihat pesanpesan dari konten-konten tentang ketahanan air tersebut. Semakin banyak masyarakat yang melihat maka semakin banyak pula masyarakat yang memiliki kesadaran akan ketahanan air tersebut. Kedua, dengan menyebarkan kontenkonten edukatif tersebut di kanal-kanal jaringan pertemanan atau media sosial berbagi video juga diharapkan semakin banyak orang yang melihat, sehingga upaya konstruksi sosial yang diharapkan tersebut dapat segera terwujud.
Akan tetapi, meskipun disebarkan di berbagai media sosial, fokus utama penyebaran tetap pada penyebaran secara langsung seperti yang dilakukan pada metode pertama. Pilihan tetap pada metode penyebaran secara langsung ini dinilai lebih efektif dan lebih bisa diukur sejauh mana keberhasilan upaya diseminasi informasi tersebut, karena interaksi secara langsung yang dilakukan. Sasaran yang menjadi target kegiatan ini adalalah masyarakat dari 20 wilayah yang berbeda dengan masing-masing wilayah diwakili oleh dua orang sehingga total masyarakat sasaran pada kegiatan ini adalah 40 orang. Selain itu 40 orang masyarakat yang menjadi sasaran pada kegiatan ini juga merupakan pengurus air di wilayah masingmasing.

\section{HASIL DAN PEMBAHASAN}

\section{Penyediaan Konten edukatif}

Secara keseluruhan, kegiatan ini dibagi menjadi beberapa tahap kegiatan, diantaranya; tahap pembuatan konten edukatif. Diseminasi isi konten-konten edukatif melalui kegiatn PPM Virtual, dan penyebaran melalui media sosial. Pada tahap pembuatan konten edukatif ini, selama satu bulan kegiatan berhasil dibuat empat jenis konten edukatif berupa booklet, leaflet, poster, video animasi dan film pendek. Proses pembuatan konten-konten edukatif tersebut melibatkan mahasiswa peserta kuliah kerja nyata virtual tahun 2021. Berikut beberapa konten edukatif yang dihasilkan selama kegiatan ini berlangsung.
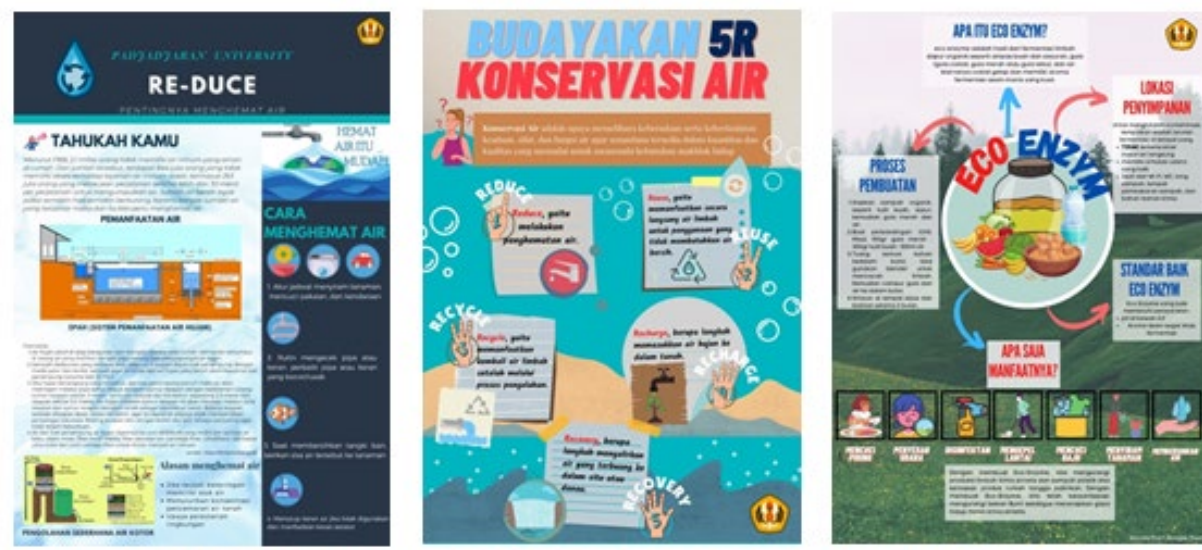

Gambar 1. Konten-konten edukatif Ketahanan Air (sumber: Tim Sosia losasi) 
Gambar 1. Merupakan konten-konten edukatif berupa poster yang, berisikan pesanpesan serta fakta-fakta tentang kondisi air, yang semakin mengalami kelangkaan. Selanjutnya, ada pula leaflet yang juga berisi tentang pesanpesan mengenai ketahanan air seperti yang terlihat pada gambar 2 .

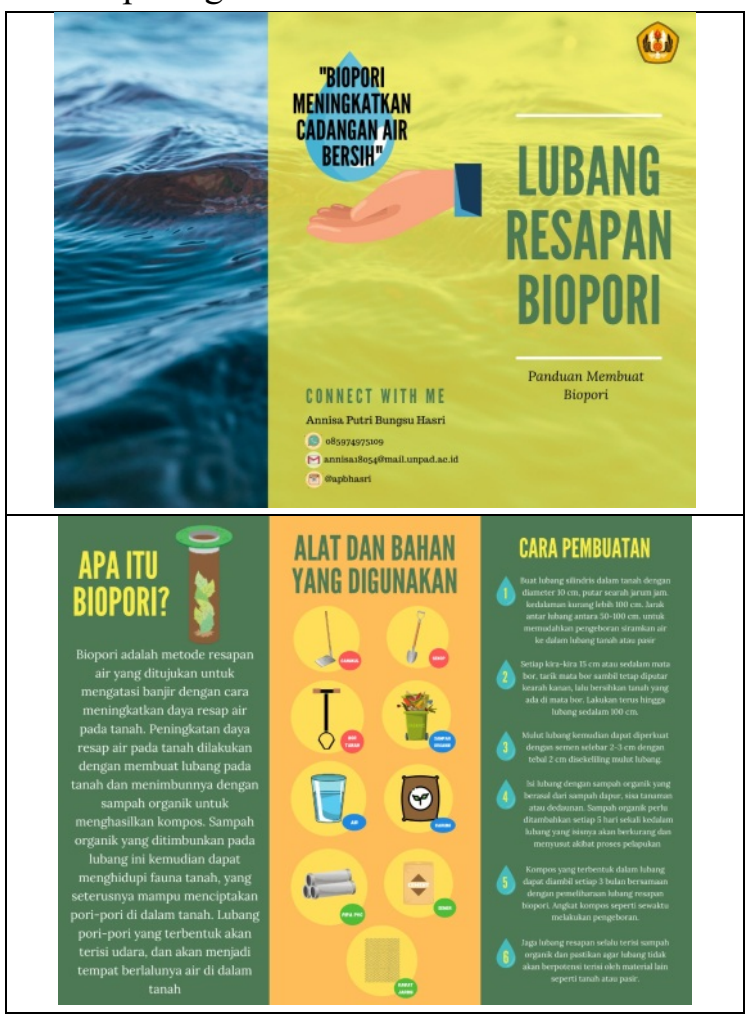

Gambar 2. Konten Edukatif berbentuk

\section{Leaflet}

(Sumber: Tim Sosialisasi)

Selanjutnya, terdapat pula konten edukatif berupa booklet yang berisi informasi dan ajakan bagi masyarakat untuk melakukan langkah-langkah pelestarian air sejak dari tingkat individu.

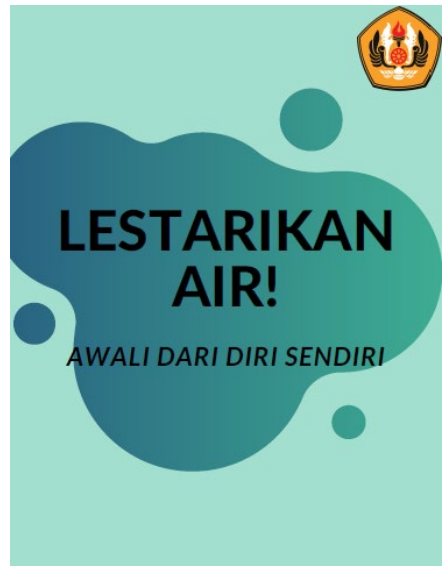

Gambar 3. Booklet Edukasi Ketahanan Air

(sumber: Tim Sosialisasi)
Selain dari konten-konten edukatif yang telah disebutkan di atas, juga konten edukatif berupa film pendek, dan video animasi yang dapat dilihat di media sosial Youtube. Penyediaan konten edukatif berupa video animasi dan film pendek ini juga diharapkan dapat menjadi salah satu strategi penyadaran yang sangat dimungkinkan untuk menjangkau lebih banyak orang, dengan harapan dengan melihat konten-konten edukatif tersebut, semakin banyak masyarakat yang tergerak untuk mulai melakukan upaya ketahanan air tersebut. Dengan semakin banyak masyarakat yang memiliki kesadaran dan tergerak untuk melakukan upaya ketahanan air tersebut, maka konstruksi sosial yang diharapkan berupa meningkatnya ketahanan air masyarakat, dapat segera terjadi.

\section{Strategi Diseminasi}

Pelaksanaan kegiatan ini dilakukan berbarengan dengan kegiatan kuliah kerja nyata mahasiswa yang dilakukan secara virtual untuk meminimalisasi risiko dan penyebaran virus Covid-19. Proses diseminasi dilakukan dengan melibatkan mitra yang mana masing-masing mitra masyarakat tersebut diwakili oleh dua orang masyarakat yang memiliki peran atau kedudukan terkait dengan pengelolaan air maupun lingkungan. Mitra-mitra yang mengikuti proses diseminasi informasi ini tersebar dari berbagai wilayah yang sebagian besar merupakan masyarakat perkotaan. Proses diseminasi diawali dengan sesi perkenalan dan pemaparan materi oleh pembimbing KKN selanjutnya berturut-turut diikuti oleh pemaparan konten-konten edukatif yang telah dibuat tersebut.

Merujuk pada proses diseminasi yang dilakukan tersebut dapat dilihat bahwa sebagian besar mitra tidak mengetahui bagaimana kondisi air yang selama ini mereka konsumsi, ketidaktahuan tersebut cukup beralasan karena mayoritas mitra tinggal di wilayah perkotaan yang notabene menggunakan air perpipaan teknis. Sehingga beberapa fakta yang diungkap di dalam konten-konten edukatif tersebut merupakan informasi yang telatif baru bagi mereka. Berdasarkan gambaran tersebut, dapat 
dilihat bahwa meskipun sedikit banyaknya masyarakat menyadari bahwa ada masalah dengan air yang selama ini mereka manfaatkan namun, banyak dari mereka yang tidak mengetahui fakta dan fenomena di balik air yang mereka manfaatkan tersebut. dengan adanya kegiatan ini telah memberikan perspektif baru dalam dalam cara berpikir masyarakat.

Berdasarkan hasil yang telah diuraikan tersebut, dapat dilihat bahwa kegiatan ini telah terlaksana dengan baik diawali dari pembuatan konten edukatif mengenai ketahanan air yang
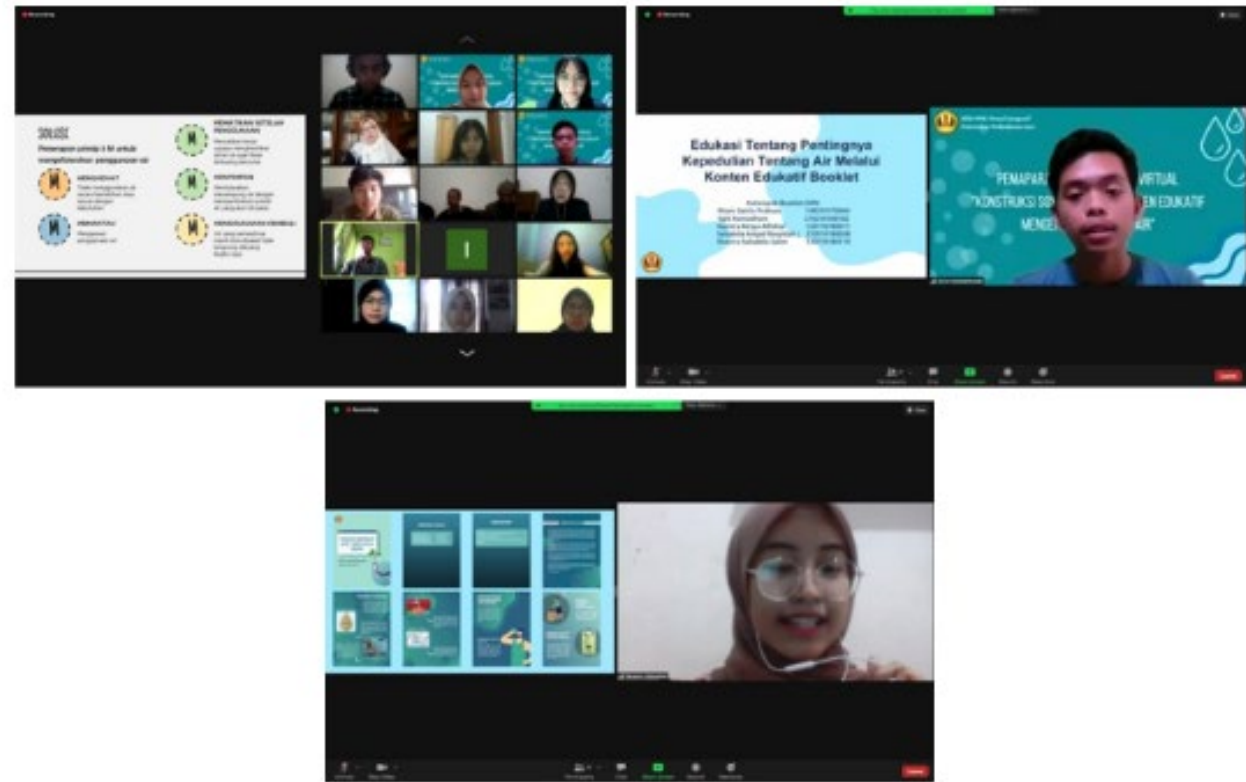

Gambar 4. Proses diseminasi Konten-konten edukatif Ketahanan Air (sumber: Tim Sosialosasi)

Secara keseluruhan proses diseminasi ini berjalan dengan sangat baik, banyak fakta dan informasi yang diberikan membuka wawasan mitra terutama fakta tentang air yang selama ini banyak mitra konsumsi. Beberapa tawaran alternatif yang ditawarkan dalam konten-konten edukatif tersebut juga sangat realistis untuk dilakukan oleh mitra-mitra pada kegiatan ini. Salah satu bentuk penerimaan yang terlihat dari para mitra tersebut secara kualitatif adalah antusiasme mitra-mitra dalam kegiatan ini untuk mendapatkan konten-konten tersebut, sehingga dapat mereka sebarkan di lingkungan mereka. Dari bentuk bentuk antusiasme yang muncul tersebut dapat dilihat bahwa kegiatan ini telah berhasil memberikan wawasan baru bagi masyarakat tentang bagiamana air dan persoalannya, serta bagaimana solusi praktis yang bisa dilakukan untuk meningkatkan ketahanan air tersebut. selanjutnya, dalam konteks konstruksi sosial, meskipun konstruksi sosial tersebut belum terlihat namun secara praktis dapat dilihat dilakukan oleh tim pada kegiatan pengabdian ini, hingga proses pada tahapan lanjut, dengan mengembangkan strategi diseminasi melalui media sosial. Jika mengikuti teori konstruksi sosial yang dirujuk dalam kegiatan ini, ketahanan air adalah objek yang menjadi perhatian pada kegiatan ini, dengan memberikan informasi dan mendiskusikannya kepada masyarakat target, diharapkan memberikan makna baru serta gagasan baru untuk meningkatkan ketahanan air tersebut, dengan tergeraknya masyarakat meningkatkan upaya ketahanan airnya maka konstruksi sosial yang dilakukan melalui kegiatan pengabdian ini dinilai berhasil, meskipun tingkat keberhasilannya hanya pada skala mikro.

\section{SIMPULAN}

Konstruksi sosial adalah suatu proses yang panjang dan bertahap. Namun dari proses kegiatan ini, adanya pemberian informasi dan fakta mengenai kondisi air yang selama ini dikonsumsi, setidaknya telah memberikan 
perspektif dan pengetahuan pada mitra bahwa kondisi ketahanan khususnya air harus menjadi salah satu wacana yang harus dikembangkan di masyarakat, sehingga upaya ketahanan air tersebut dapat diterapkan setidaknya dilingkungan tempat mitra tersebut tinggal. Selanjutnya, melihat bahwa sebagian besar mitra tidak mengetahui fakta tentang air yang selama ini menjadi kebutuhan tersebut, maka sudah selayaknya upaya-upaya penyebaran informasi melalui konten-konten edukatif mengenai ketahan air ini harus terus dilaksanakan, dengan harapan akan terbangun perspektif berpikir dimasyarakat yang suatu saat akan menjadi tindakan nyata seperti ideal yang diharapkan dari teori konstruksi sosial.

\section{UCAPAN TERIMA KASIH}

Ucapan terima kasih ditujukan kepada DRPMI Universitas Padjadjaran yang telah memberikan dukungan dana untuk terlaksananya kegiatan PPM ini melalui kegiatan Kuliah Kerja Nyata (KKN) Virtual tahun 2021.

\section{DAFTAR PUSTAKA}

Alwang, Jeffrey; Siegel, Paul B.; Jorgensen, Steen (June 2001). Vulnerability: a view from different disciplines. PDF Report

Anderson, Mary B; Woodrow, Peter J (1998). Rising From the Ashes: Development Strategies in Times of Disaster. London: IT Publications. ISBN 978-1-85339-439-

\section{OCLC 878098209.}

Arup and The Rockefeller Foundation. (2014a). City Resilience Index. Research Report Volume 1: Desk Study.

Conway, Tim; Norton, Andy (November 2002). "Nets, Ropes, Ladders and Trampolines: The Place of Social Protection within Current Debates on Poverty Reduction". Development Policy Review. 20 (5): 533-

540. doi:10.1111/1467-

7679.00188. S2CID 154218764.

Cooley, Heather, et.al. 2020. Water and the Covid-19 Pandemic. Impact on municipal water demand. Pacific Institue Issue Brief. July 2020
Fletcher, Mark. 2019. The City Water Resilience Approach. Arup and The Rockefeller Foundation. 2019

Gößling-Reisemann, S., Hellige, H. D., \& Thier, P. (2018). The Resilience Concept: from its historical roots to theoretical framework for critical infrastructure design. (artec-paper, 217). Bremen: Universität Bremen, Forschungszentrum Nachhaltigkeit (artec). https://nbnresolving.org/urn:nbn:de:0168-ssoar59351-6

Gunawan, Wahyu \& Dianne Wahyu Kusuma. 2020. Kegiatan Pemberian Bantuan Sosial Pandemi Covid-19 Di Desa Sekitar Kampus Unpad Jatinangor. Jurnal Kumawula. Volume 3. Nomor 3. 2020 .

Johannessen, A. and C. Wamsler. 2017. What does resilience mean for urban water services? Ecology and Society Vol. 22, No.

https://www.jstor.org/stable/26270048 https://doi.org/10.5751/ES-08870220101

Lawrenche, F., Wulandari, N., Ramadhan, N., Rahayu, F., Bakhtiar, M. A., \& Nurrachmawati, A. (2020). Pemberdayaan Masyarakat Dimasa Pandemi Covid-19 Pada Ikatan Remaja Masjid RT.04 Loa Kulu. Kumawula: Jurnal Pengabdian Kepada Masyarakat, 3(3), 429-434.

https://doi.org/10.24198/kumawula.v3i3. 28007

Leeds-Hurwitz, Wendy (2009). "Konstruksi sosial dari realitas". Dalam Littlejohn, Stephen W .; Foss, Karen A. (eds.). Ensiklopedia teori komunikasi . Thousand Oaks, California: SAGE

Publications . p. 891 . doi : 10.4135 9781412959384.n344 . ISBN 978-14129-5937-7.

Ngangi, Charles R. 2021. Konstruksi sosial dalam realitas sosial. AgriSosioEkonomi Journal Volume 7 Nomor 2. 2011:1-4

Peacock, Walter G; Ragsdale, A Kathleen (1997). "Social systems, ecological networks and disasters: Toward a sociopolitical ecology of disasters". Hurricane 
Andrew: Ethnicity, Gender, and the Sociology of Disasters. pp. 2035. doi:10.4324/9780203351628-

11. ISBN 9780203351628.

Purwanto, Eko Wiji. 2020. Pembangunan Akses Air Bersih Pasca Krisis Covid-19. The Indonesia Journal of Developing Planning. Volume IV No. 2. 2020. Pp. 207-214

United Nation International Strategy for Disaster Risk Reduction (UNISDR). 2009. Terminology on disaster risk reduction. UNISDR, Geneva, Switzerland. [online] URL: http://www.unisdr.org/we/inform/termin ology 